\begin{tabular}{|l|l|l||}
\hline \multicolumn{2}{|c|}{ PublisherInfo } \\
\hline \hline PublisherName & $:$ & BioMed Central \\
\hline \hline PublisherLocation & $:$ & London \\
\hline \hline PublisherImprintName & $:$ & BioMed Central \\
\hline \hline
\end{tabular}

\title{
Conditional switching of VEGF expression in VEGF-driven
} angiogenesis

\begin{tabular}{||l|l|l||}
\hline \multicolumn{2}{|c|}{ ArticleInfo } \\
\hline \hline ArticleID & $:$ & 256 \\
\hline \hline ArticleDOI & $:$ & $10.1186 /$ ar-2002-77600 \\
\hline \hline ArticleCitationID & $:$ & 77600 \\
\hline \hline ArticleSequenceNumber & $:$ & 9 \\
\hline \hline ArticleCategory & $:$ & Paper Report \\
\hline \hline ArticleFirstPage & $:$ & 1 \\
\hline \hline ArticleLastPage & $:$ & 3 \\
\hline \hline & & RegistrationDate $: 2002-7-24$ \\
ArticleHistory & $:$ & Received \\
& Accepted $2002-7-24$ \\
& $: 2002-8-22$ \\
\hline \hline ArticleCopyright & $:$ & Biomed Central Ltd2002 \\
\hline \hline
\end{tabular}




\begin{tabular}{|l|l|l||}
\hline ArticleGrants & $:$ & \\
\hline \hline ArticleContext & $:$ & 130754411 \\
\hline
\end{tabular}

Ewa Paleolog, Aff1

Aff1 Kennedy Institute of Rheumatology Division, London, UK

\section{Keywords}

angiogenesis, VEGF

\section{Context}

During rheumatoid arthritis (RA), blood vessels maintain and promote the synovium. It has been suggested that inhibition of angiogenesis could be a useful therapeutic modality in RA. However, concerns abound that angiogenesis blockade might promote the incidence of cardiovascular events, which are already more common in RA. Conversely, upregulation of angiogenesis has been proposed as a therapeutic target for the treatment of ischemia. However, there have been suggestions that proangiogenic therapy may in itself result in potential problems. This paper aims to examine VEGF-driven angiogenesis using a transgenic system for conditional switching of VEGF expression. The authors make a case that the quality of blood vessels formed and the consequences of growth factor withdrawal at the end of the treatment, need to be considered.

\section{Significant findings}

Mice expressing a tetracycline-regulated transactivator protein in the myocardium or liver were crossed with mice carrying VEGF-164 driven by a tetracycline-responsive promoter (repressed by tetracycline administration). Both heart- and liver-specific induction of VEGF resulted in the formation of large abnormal vessel structures, with chaotic connections within the existing network. A proportion of these vessels were associated with smooth muscle cells. Importantly, excessive vessel permeability and resultant oedema were observed. Following inclusion of tetracycline, most abnormal vessels disappeared. However, delaying the 'off' switch until 4 weeks after the formation of these vessels did not lead to dissolution of the abnormal vessels. 


\section{Comments}

Forced formation of blood vessels may not yield functional vascular structures, and may complicate attampts to delelop pro-angiogenic therapy. Despite these potential obstacles, the observation that the timing of VEGF-based therapy may still be a viable option. There is clearly a delicate balance between the "beneficial" (as in ischemic disease) and "harmful" (as in RA) effects of VEGF on the angiogenic process.

\section{Methods}

VEGF expression: in situ hybridisation; nothern blotting; ELISA. Vascular function: MRI; corrosion casts.

\section{References}

1. Dor Y, Djonov V, Abramovitch R, Itin A, Fishman GI, Carmeliet P, Goelman G, Keshet E:

Conditional switching of VEGF provides new insights into adult neovascularization and pro-angiogenic therapy. EMBO J. 2002, 21: 1939-1947.

This PDF file was created after publication. 